\title{
ICE CORE RECONSTRUCTION OF ANTARCTIC CLIMATE CHANGE AND IMPLICATIONS
}

\author{
RECONSTRUCCIÓN DEL CAMBIO CLIMÁTICO EN ANTÁRTICA Y \\ SUS REPERCUSIONES BASADAS EN TESTIGOS DE HIELO
}

Paul Andrew Mayewski ${ }^{1}$

\begin{abstract}
RESUMEN
La Antártica es la biblioteca medioambiental de testigos de hielo más grande del planeta. Algunos ejemplos de los hallazgos científicos del consorcio de 21 países llamado la Expedición Científica Internacional Trans Antártica (ITASE), bajo los auspicios del Comité Científico de Investigaciones Antárticas (SCAR) se presentan con especial énfasis en el valor de estos registros en la reconstrucción de la circulación atmosférica sobre la Antártica y el Océano Austral.
\end{abstract}

Palabras clave: Antártica, Océano Austral, testigos de hielo, cambio climático, ITASE, SCAR.

\begin{abstract}
Antarctica is the Earth's largest environmental library for ice cores. Examples of the scientific findings of the 21-nation consortium called the International Trans Antarctic Scientific Expedition (ITASE) under the auspices of the Scientific Committee for Antarctic Research (SCAR) are presented with special emphasis on the value of these records in reconstructing atmospheric circulation over Antarctica and the Southern Ocean.
\end{abstract}

Key words: Antarctica, Southern Ocean, ice cores, climate change, ITASE, SCAR. 


\section{INTRODUCTION}

Antarctica plays a critical role in the dynamic linkages that couple the spatially and temporally complex components of the Earth's system (atmosphere, biosphere, anthrosphere, hydrosphere, cryosphere, lithosphere and cosmogenic input). However, our knowledge of the functioning of Antarctica within the global system and the spatial and temporal complexity of Antarctic climate is poor, largely due to the limitations and the short period (typically 30-50 years) of observational and instrumental data on Antarctic climatic variables. Further, Antarctica exhibits significant regional contrasts, including decoupling of climate change on decadal scales between different parts of the continent. Large areas of the interior of the ice sheet are influenced by the continental temperature inversion while other portions of the interior and the coastal regions are influenced by the incursion of cyclonic systems that circle the continent. As a consequence these coastal regions are mainly connected with lower tropospheric transport whereas high altitude regions in the interior are more likely influenced by vertical transport from the upper troposphere and stratosphere. As a result the coastal regions experience higher climatic variability than regions in the interior. Further, high frequency climatic changes impact both Antarctica and the surrounding Southern Ocean. Some may be related to the $\mathrm{El}$ Niño Southern Oscillation (ENSO) and other local to regional to global scale climate features such as: atmospheric blocking, sea-ice variations and volcanic event induced atmospheric shielding.

Ice cores can provide robust reconstructions of basic boundary conditions (e.g., sea surface temperature, precipitation and atmospheric circulation patterns) necessary for robust environmental reconstructions. Along with other high-resolution paleo-records, ice core records provide detailed descriptions of climate change that are extremely valuable for comparison with modern observations. Further, they document not only a wide range of environmental parameters that are both measures of and responses to climate change (eg., atmospheric chemistry and circulation, temperature, precipitation) but also many of the causes of climate change (eg., solar variability, volcanic activity, greenhouse gases). Because of their potential resolution (sub-annual), length (several glacial cycles) and in some cases precise dating (sub-annual) they also provide a framework for relating other records of past climate. Over time periods longer than the instrumental era ice core studies demonstrate that Antarctica experienced millennial to decadal scale climatic variability that is associated with significant changes in temperature, snow accumulation, wind-blown dust, sea-salt loading and greenhouse gas composition.

The International Trans Antarctic Scientific Expedition (ITASE) is a multi-national, multidisciplinary field research program with the broad aim of understanding the recent environmental history of Antarctica. ITASE is organized under the auspices of SCAR and now comprises twenty-one countries. An emerging compilation of all ITASE and other ice core sites is available through Ice READER (http://www.icereader.org/) and summaries of ITASE national products are available through (http://www2.umaine.edu/itase/content/ nationals/index.html).

International ITASE representatives have met several times in the past to: discuss national traverse plans; coordinate efforts; synthesize results; develop statistical techniques for interpretation; and interact with the broader scientific community. These all-ITASE meetings started with a workshop that led to the development of an international Science and Implementation Plan for ITASE (Mayewski and Goodwin, 1997) followed by meetings in Durham, New Hampshire (1999), Potsdam, Germany (2002), Milan, Italy (2003), Hobart, Australia (2006), and in 2008 an NSF-SCAR sponsored workshop in Maine, USA. These meetings have provided an important opportunity for ITASE researchers to meet and exchange information.

Primary ITASE emphasis is placed on the last 200 years of the record although many ITASE projects have sampled significantly longer periods of $1000+$ years. The minimum $\sim 200$ year time period was selected because it covers the onset of major anthropogenic influence on the atmosphere and the end of the Little Ice Age. Further, the Tambora volcanic eruption (AD 1815) and other volcanic events provide an excellent absolute marker for age calibration of these records. In addition, overland snow traverse programs can logistically handle the collection and transport of multiple 200-year long ice cores. 


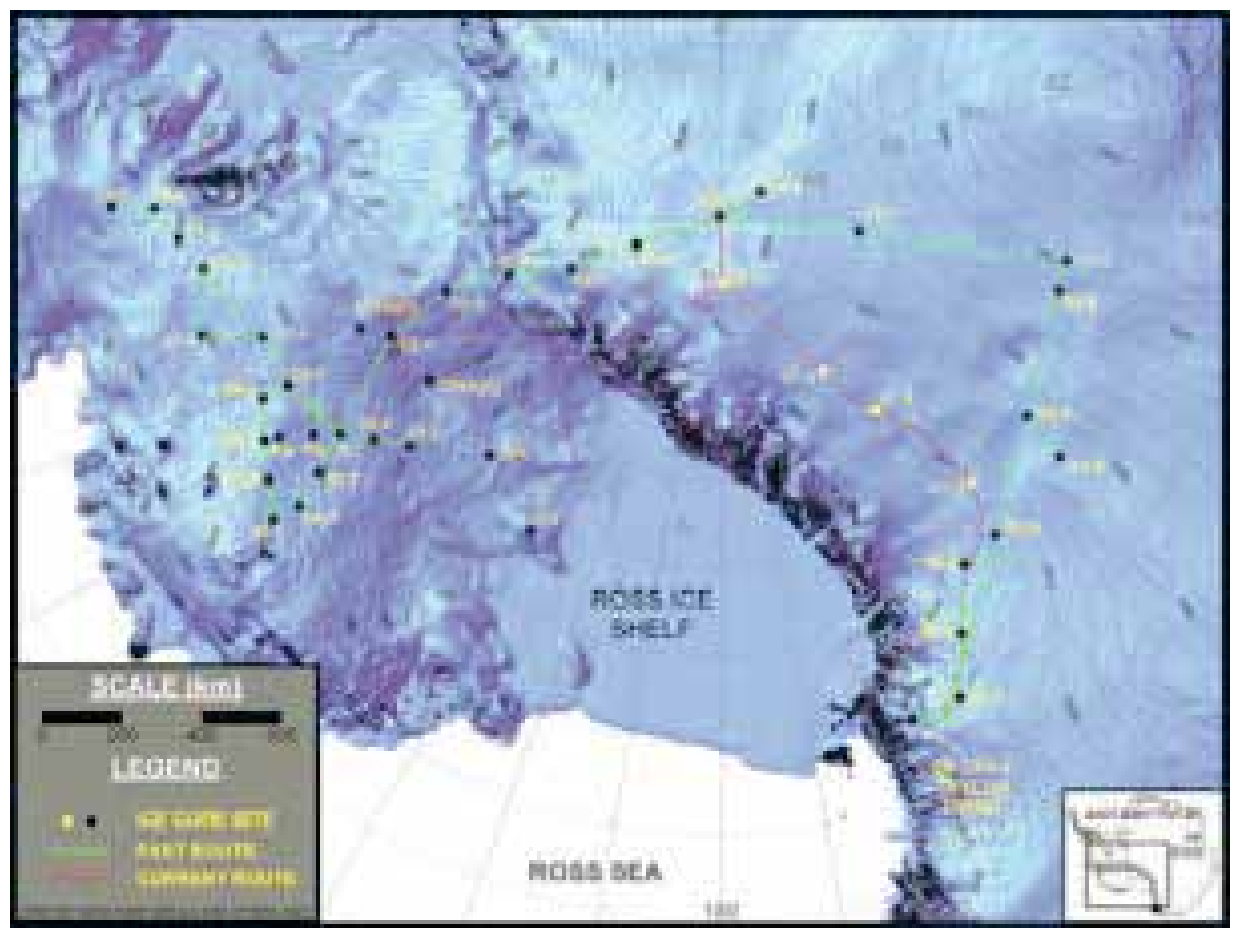

Fig. 1. US ITASE routes and core sites.

Since 1999, US ITASE has traversed $>10,000$ $\mathrm{km}$ throughout West and East Antarctica (Fig. 1) and collected a total of $3945 \mathrm{~m}$ of ice cores. Together with six shallow cores collected in conjunction with the Long Ground Traverse, US ITASE has conducted scientific investigations (ice coring, surface glaciology, radar) at 45 sites and radar (crevasse, shallow, and deep) along almost the entire $>10,000 \mathrm{~km}$ route. US ITASE has focused on sampling the ice climate record surrounding the Ross Ice Shelf and hundreds of $\mathrm{km}$ inland. US ITASE has now completed six field seasons of multi-disciplinary research setting a new benchmark for Antarctic climate multi-disciplinary research.

\section{SUMMARY OF RESULTS}

ITASE findings are published in well over 150 peer-reviewed publications (see summaries in Mayewski (2003, 2006) and Mayewski et al. (2006). Examples, arranged by area of scientific contribution, are listed belowIdentification of seasonal timing, source contributions, and controls on spatial distribution for all major ions (e.g. Kaspari et al. 2005; Kaspari et al. 2004; Dixon et al. 2004; Pruett et al. 2004; Han et al. 2001; Isaksson et al. 2001; Steig et al. 2006, Bertler et al. 2006a).

Precise annual layer counting of ice cores resulting in estimates of past mass balance, identification of moisture source regions, and environmental interpretations (e.g. Kaspari et al. 2004; Kaspari et al. 2005; Dixon et al. 2004; Spikes et al. 2004; Steig et al. 2006).

Direct linkage between ice core glaciochemical markers and shallow and deep radar reflectors, demonstrating that the latter are isochrones and therefore yield 3-D mass balance reconstructions (e.g. Spikes et al. 2004; Arcone et al. 2005).

Highly resolved temporal and spatial volcanic event records, and identification of stratospheric versus tropospheric source volcanic emission input pathways to Antarctica and utilization of stratospheric source events as evidence of emission plume history over the ice sheet (e.g. Dixon et al. 2004; Kurbatov et al. 2006).

Differentiation of the relative influence of sea salt spray and salt flowers on $\mathrm{Na}^{+}$loading over Antarctica (e.g. Kaspari et al. 2005).

Instrumental record calibrated proxies using ice chemistry and isotope tracers from multiple ice 
cores for: Amundsen Sea Low, East Antarctic High, ENSO, ice surface wind drainage, the Antarctic Oscillation, the Southern Hemisphere westerlies (e.g. Meyerson et al. 2002; Bertler et al. 2004; Kreutz et al. 2000; Souney et al. 2002; Goodwin et al. 2003; 2004, Shulmeister et al. 2004; Kaspari et al. 2005; Yan et al. 2005; Mayewski et al. 2004, 2005; Schneider and Steig 2006).

Integration of ITASE spatial records with deep ice core records to significantly refine paleoclimate reconstructions and other global scale abrupt climate change correlations (e.g. Mayewski et al. 2004, 2005; Shulmeister et al. 2004; Mayewski and Maasch 2006).

Proxies for sea ice extent, a critical component in the climate system, through studies of sulfur compounds (e.g. Dixon et al. 2005).

The "Solar Polar" hypothesis for the initiation of annual to decadal scale climate variability over Antarctica and the Southern Ocean and potentially for global scale abrupt climate change events (e.g. Mayewski et al. 2005; Maasch et al. 2005).

Definition and understanding of the current state of the Antarctic climate system relative to the last few hundred years (Mayewski and Maasch 2006; Schneider et al. 2006; Mayewski et al. 2009).

Large-scale calibrations between satellite observations, surface snow properties, and ITASE ice core proxies for temperature (e.g. Schneider and Steig, 2002; Schneider et al. 2004, 2005; Steig et al. 2008; Koenig et al. 2007; Winebrenner et al. 2004).

ENSO - sea ice connections utilizing ice core sulfur chemistry over the Ross Sea embayment region (e.g. Meyerson et al. 2002).

Partitioning of the sources of sulfate using sulfur isotopes as an aid to further refining air mass trajectory fingerprinting and the sulfur cycle over Antarctica (Pruett et al. 2004).

Site selection for potential new deep drilling projects (e.g. Jacobel et al. 2005; Conway et al. 2005).

Documentation of the impact of solar forcing (via UV induced changes in stratospheric ozone concentration) on zonal westerlies at the edge of the polar vortex (Mayewski et al. 2005; Bertler et al. 2006b).

Distribution of snow precipitation over the Antarctic continent on varying spatial and temporal scales and dependence on wind and surface slope (e.g. Spikes et al. 2005).

Production of a global array of high resolution, multi-proxy records of Holocene climate (e.g. Mayewski et al. 2004; Maasch et al. 2005).

Compilation of an Antarctic wide array of glaciochemical and isotopic data (e.g. Bertler et al. 2006b; Masson-Delmotte et al. 2008).

Comparison between ITASE climate proxies and model results (e.g. Genthon et al. 2005; Schneider et al. 2006; Monaghan et al. 2006; Schneider and Noone, 2007).

Refined estimates of Antarctic surface mass balance (Monaghan et al. 2006; Genthon et al. 2005).

\section{CONCLUSIONS}

The 21-nation ITASE effort has made highly notable advances in the understanding of Antarctic climate variability and raised the bar on the previous standards of ice core research. Several countries have focused through ITASE and their national and international deep ice coring efforts on West and East Antarctica yielding superb climate records extending back in time 850,000 years and a new program promises a record that will extend back at least one and possibly more than two million years.

The Antarctic Peninsula has experienced the greatest recent changes in climate as demonstrated by a broad range of investigations (e.g. glaciology, meteorology, biology, oceanography). Ice core reconstructions conducted by several national and multi-national programs (e.g. Brazil, Chile, China, United Kingdom, and United States) on the Antarctic Peninsula and surrounding regions begin to demonstrate the evolution of recent climate change in this region. A relatively new multi-national effort (CASA - Climate of Antarctica and South America) including Brazil, Chile, New Zealand, and the US offers significant promise for deep ice coring climate reconstructions on the northernmost suitable ice coring site on the Antarctic Peninsula, the Detroit Plateau. This site in conjunction with the recently completed deep ice core on James Ross Island produced by the UK are essential to understanding past, present and future climate change in the highly critical interface between Antarctica and South America (Fig. 2). 


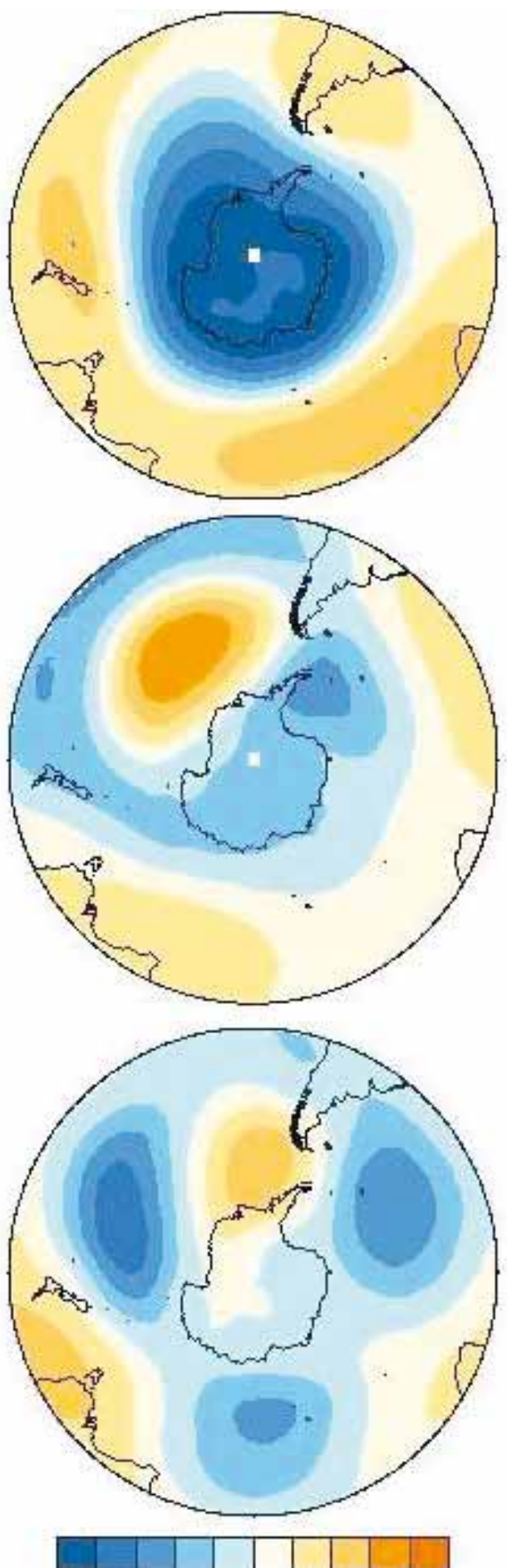

Fig. 2. (a)-(c) The first three EOF modes of monthly areaweighted 850-hPa pressure surface height anomalies (plotted as correlations). The data were reduced by sampling every third point in the zonal direction $\left(7.5^{\circ}\right)$ between $82^{\circ}$ and $30^{\circ} \mathrm{S}$ and then normalized by cosine of latitude, prior to the decomposition, in order to ensure a equal area representation. The cosine latitude factor was multiplied back to the pattern prior to display. (d)-(f) The principal component of the three EOFs (SAM, PSA-1, and PSA-2, respectively) are given in geopotential meters. The principal component time series PSA-1 and PSA- 2 are shown together with scaled Niño-3 SST anomalies (yellow) for reference to ENSO. Taken from Thompson and Solomon (2002). 
It is clear that the geography of the Antarctic Peninsula and southern South America exert significant influences on atmospheric circulation in the Southern Hemisphere and that this region is particularly sensitive to climate change.

\section{LITERATURE CITED}

Arcone, S. A., V.B. Spikes, G. Hamilton, \& P.A. Mayewski 2005. Continuity, vertical resolution and origin of stratigraphy in 400-Mhz shortpulse radar profiles of firn in West Antarctica, Annals of Glaciology, 39:195-200

Bertler, A.N., P.J. Barrett, P.A Mayewski, S.B. Sneed, T.R. Naish \& U. Morgenstern 2006a. Solar forcing recorded by aerosol concentrations in coastal Antarctic glacier ice, McMurdo Dry Valleys, Annals of Glaciology, 41:52-56

Bertler, N., P.A. Mayewski, A. Aristarain, P. Barrett, S. Becagli, R. Torma, B. Xiao Cunde, M. Curran, Qin Dahe, D. Dixon, Francisco Adolfo Ferron, H. Fischer, Markus Frey, M. Frezzotti, F. Fundel, C. Genthon, R. Gragani, G. Hamilton, M. Handley, Sungmin Hong, E. Isaksson, R. Jiawen, K. Kamiyama, S. Kanamori, E. Karkas, L. Karlöf, S. Kaspari, K. Kreutz, A. Kurbatov, E. Meyerson, H. Motoyama, R. Mulvaney, Z. Mingjun, H. Oerter, E. Osterberg, M. Proposito, A. Pyne, U. Ruth, J. C. Simoes, B. Smith, S. Sneed, K. Teinila, F. Traufetter, R. Udisti, A. Virkkula, O. Watanabe, B.Williamson, E. Wolff \& Li Zhongqin 2006. Snow chemistry across Antarctica, Annals of Glaciology, 41:167-179 Bertler, N.A.N., P.J. Barrett, P.A. Mayewski, R.L. Fogt, K.J. Kreutz \& J. Shulmeister 2004b. El Niño suppresses Antarctic warming, Geophysical Research Letters, 31 (L15207, doi: 10.1029/2004GL020749).

Conway, H., T.A. Neumann, S. Price, E.D. Waddington, D. Morse, K. Taylor, P.A. Mayewski, D. Dixon, E. Pettit \& E.J. Steig 2005. Candidate drill site near the Ross-Amundsen ice divide, West Antarctica, Report to Office of Polar Programs, National Science Foundation, 10p.

Dixon, D., P.A. Mayewski, S. Kaspari, S. Sneed \& M. Handley 2005. Connections between West Antarctic ice core sulfate and climate over the last 200+ years, Annals of Glaciology, 41:155-156
Dixon, D., P.A. Mayewski, S. Kaspari, S. Sneed \& M. Handley 2004. A 200 year sub annual record of the primary sources of sulfate in West Antarctica, Annals of Glaciology, 39:545-556

Genthon, C., S. Kaspari \& P.A. Mayewski 2005. Inter-annual variability of surface mass balance in West Antarctica from ITASE cores and ERA40 reanalyses, Climate Dynamics, 21: DOI 10.1007/s00382-003-0329-1.

Goodwin, I. D., T.D. Van Ommen, M.A.J. Curran \& P.A. Mayewski 2004. Mid latitude winter climate variability in the south Indian and south-west Pacific regions since 1300 AD, Climate Dynamics, 22: 783-794, DOI:10.1007/ S00382-004-0403-3.

Goodwin, I., M. de Angelis, M. Pook \& N.W. Young 2003. Snow accumulation variability in Wilkes Land, East Antarctica and the relationship to atmospheric ridging in the $130^{\circ}$ to $170^{\circ} \mathrm{E}$ region since 1930 , Journal of Geophysical Research, 108: D21, 4673, doi:10.1029/2002JD002995.

Han, J., Xie, Z. Zhang, Z. Xinping, Dai \& P.A. Mayewski 2001. Methanesulfonate in the firn of King George Island, Antarctica, Journal of Glaciology, 47 (159):589-594

Isaksson, E., W. Karlén, P. Mayewski, M. Twickler \& S. Whitlow 2001. A high-altitude snow chemistry record from Amundsenisen, Dronning Maud Land, Antarctica. Journal of Glaciology, 47 (158):489-496

Jacobel R, B. Welch, E.J. Steig, D.P. Schneider 2005. Hercules Dome, Antarctica - an optimal site for deep ice core drilling. Journal of Geophysical Research - Earth Surface 110: F01015, doi:10.1029/2004JF000188

Kaspari, S., P.A. Mayewski, D. Dixon, S.B. Sneed \& M.J. Handley 2005. Sources and transport pathways for marine aerosol species into West Antarctica, Annals of Glaciology, 42:1-9

Kaspari, S., P.A. Mayewski, D. Dixon, V.B. Spikes, S.B. Sneed, M. Handley \& J. Hamilton 2004. Climate variability in West Antarctica derived from annual accumulation rate records from ITASE firn/ice cores, Annals of Glaciology, 39:585-594

Koenig LS, E.J. Steig, D.P. Winebrenner \& C.A. Shuman 2007. A link between microwave 
extinction length, firn thermal diffusivity and accumulation rate in West Antarctica. Journal of Geophysical Research, 112, F03018, doi:10.1029/2006JF000716

Kreutz, K.J., P.A. Mayewski, I.I. Pittalwala, L.D. Meeker, M.S. Twickler \& S.I. Whitlow 2000. Sea-level pressure variability in the Amundsen Sea region inferred from a West Antarctic glaciochemical record, Journal of Geophysical Research, 105 (D3):4047-4059

Kurbatov, A.V., G.A. Zielinski, N.W. Dunbar, P.A. Mayewski, E.A. Meyerson, S.B. Sneed \& K.C. Taylor 2006. A 12,000 year record of explosive volcanism in the Siple Dome Ice Core, West Antarctica, Journal of Geophysical Research, 111, D12307, doi:10.1029/2005JD006072.

Maasch, K., P.A. Mayewski, E. Rohling, C. Stager, K. Karlén, L.D. Meeker \& E. Meyerson 2005. Climate of the past 2000 years, Geografiska Annaler, 87A (1):7-15

Mayewski, P.A. and I. Goodwin, 1997, ITASE Science and Implementation Plan, Joint PAGES/ GLOCANT Report.

Mayewski, P.A. \& K. Maasch 2006. Recent warming inconsistent with natural association between temperature and atmospheric circulation over the last 2000 years, Climate of the Past (Discussions), on line: http://www.copernicus. org/EGU/cp/cpd/2/327/cpd-2-327.htm.

Mayewski, P.A. 2003. Antarctic oversnow traversebased Southern Hemisphere climate reconstruction, EOS, 84, 22, 205 and 210.

Mayewski, P.A. 2006. ITASE (International Trans Antarctic Scientific Expedition), PAGES March 2006.

Mayewski, P.A., M. Frezzotti, N. Bertler, T. van Ommen, G.H. Hamilton, J. Jacka, B. Welch, M. Frey, Q. Dahe, J. Ren, J. Simoes, M. Fily, H. Oerter, F. Nishio, E. lasaksson, R. Mulvaney, P. Holmund, V. Lipenkov \& I. Goodwin 2006. The International Trans-Antarctic Scientific Expedition (ITASE) - An Overview, Annals of Glaciology, 41:180-185

Mayewski, P.A., K. A. Maasch, J.W.C. White, E. Meyerson, I. Goodwin, V.I. Morgan., T. van Ommen, M.A.J. Curran, J. Souney \& K. Kreutz 2005. A 700 year record of Southern Hemisphere extra-tropical climate variability, Annals of Glaciology, 39:127-132
Mayewski, P.A., M. Meredith, C. Summerhayes, J. Turner, S. Aoki, Barrett, P. N.A.N. Bertler, T., Bracegird,le, D. Bromwich, H. Campbell, G. Casassa, A. N. , Garabato, W.B. Lyons, K.A. Maasch, A. Worby \& C. Xiao 2009. State of the Antarctic and Southern Ocean Climate System (SASOCS), Journal of Geophysical Research, 47, RG1003, doi:10.1029/2007RG000231. Mayewski, P.A., K. Maasch, Y. Yan, S. Kang, E. Meyerson, S. Sneed, S. Kaspari, D. Dixon, V. Morgan, T. van Ommen \& M. Curran 2006. Solar forcing of the polar atmosphere, Annals of Glaciology, 41:147-154

Mayewski, P.A., E. Rohling, C. Stager, K. Karlén, K. Maasch, L.D. Meeker, G. Meyerson, E. Gasse, F. van Kreveld, S. Holmgren, K. Lee-Thorp, J. Rosquist, G. Rack, F. M. Staubwasser \& R. Schneider 2004. Holocene climate variability, Quaternary Research, 62:243-255

Meyerson, E.A., P.A. Mayewski, S.I. Whitlow, L.D. Meeker, K.J. Kreutz \& M.S. Twickler 2002. The extratropical expression of ENSO recorded in a South Pole glaciochemical time series, Annals of Glaciology, 35:430-436

Monaghan, A.J., D.H. Bromwich, R.L. Fogt, S.H. Wang, P.A. Mayewski, D.A. Dixon, A. A. Ekaykin, M. Frezzotti, I.D. Goodwin, E. Isaksson, S.D. Kaspari, V.I. Morgan, H. Oerter, T. D. van Ommen, C. J. van der Veen \& J. Wen. 2006b. Insignificant change in Antarctic snowfall since the International Geophysical Year, Science, 313:827-831

Pruett, L.E., K.J. Kreutz, P.A. Mayewski, A. Kurbatov \& M. Wadleigh 2004. Sulfur isotopic measurements from a West Antarctic ice core: implications for sulfate source and transport, Annals of Glaciology, 39:161-168.

Schneider D.P. \& D.C. Noone 2007. Spatial covariance of water isotope records in a global network of ice cores spanning twentieth-century climate change, Journal of Geophysical Research, 112, D18105, doi:10.1029/2007JD008652.

Schneider, D.P., E.J. Steig \& J. Comiso 2004. Recent climate variability in Antarctic from satellite-derived temperature data, Journal of Climate, 17(7):1569-1583

Schneider, D. \& E.Steig 2002. Spatial and temporal variability of Antarctic ice sheet micro- 
wave brightness temperatures, Geophysical Research Letters, 29(20) 25-1-25-4.

Schneider, D. P., E. J. Steig, T. D. van Ommen, D. A. Dixon, P. A. Mayewski, J. M. Jones, \& C. M. Bitz 2006. Antarctic temperatures over the past two centuries from ice cores, Geophysical Research Letters, 33, L16707, doi:10.1029/2006GL027057.

Schneider, D., E. Steig \& T. Van Ommen 2005. High-resolution ice-core stable-isotopic records from Antarctica: towards interannual climate reconstruction, Annals of Glaciology, 41(8):63-70

Shulmeister, J., I. Goodwin, J. Renwick, K. Harle, L. Armand, M. S. McGlone, E. Cook, J. Dodson, Hesse, P.A, Mayewski \& M. Curran 2004. The Southern Hemisphere Westerlies in the Australasian sector: A synthesis, Quaternary International, 118-119:23-53

Souney, J., P.A. Mayewski, I. Goodwin, V. Morgan \& T.van Ommen 2002. A late Holocene climate record from Law Dome, East Antarctica, Journal of Geophysical Research, 107 (D22), 4608.

Spikes, V.B., G.H. Hamilton, S.A. Arcone, S. Kaspari \& P.A. Mayewski 2005. Primary causes of variability in Antarctic accumulation rates, Annals of Glaciology, 39:238-244

Spikes, V.B., G.S., Hamilton, S.A., Arcone, S. Kaspari, P.A. Mayewski 2004. Variability in accumulation rates from GPR profiling on the
West Antarctic plateau, Annals of Glaciology, 39:238-244

Steig, E.J., P.A. Mayewski, D. Dixon, S. Kaspari, M. Frey, D.P. Schneider, S.A. Arcone, G. Hamilton, B. Spikes, M.R. Albert, D.A. Meese, A. Gow, C.A. Shuman, J. White, S. Sneed, J. Flaherty, M. Wumkes \& US ITASE Project Members, 2006. High-resolution ice cores from US ITASE (West Antarctica): development and validation of chronologies and determination of precision and accuracy, Annals of Glaciology, 41:77-84

Thompson, D.W.J. \& S. Solomon 2002. Interpretation ofrecent Southern Hemisphere climate change, Science, 296: 895-899, doi:10.1126/ Science.1069270.

Winebrenner, D.P., E.J. Steig \& D.P. Schneider 2004. Relationship between surface air temperatures and microwave brightness temperatures in Antarctica. Annals of Glaciology, 39:346-350

Xiao, C., P.A. Mayewski, D. Qin, Z. Li, M. Zhang \& Y. Yan in press, Sea level pressure variability in the Southern Indian Ocean inferred from a glaciochemical record in the Princess Elizabeth L and East Antarctica, Journal of Geophysical Research, 109.

Yan, Y., P.A. Mayewski, S. Kang \& E. Meyerson 2005. An ice core proxy for Antarctic circumpolar wind intensity, Annals of Glaciology, 41:121-130 